\title{
The population of donkeys and mules in Brazil according to agricultural censuses from 1960 to 2017
}

\author{
População de jumentos e muares no Brasil segundo os censos \\ agropecuários de 1960 a 2017
}

\author{
Mariana Ramos Queiroz ${ }^{1}$ (D); Mariana Bombo Perozzi Gameiro ${ }^{1}$ (D); Adroaldo José Zanella ${ }^{1}$ \\ ${ }^{1}$ Universidade de São Paulo, Faculdade de Medicina Veterinária e Zootecnia, Departamento de Medicina Veterinária Preventiva e \\ Saúde Animal, São Paulo - SP, Brazil
}

\begin{abstract}
To better understand and manage the population of donkeys and mules, it is essential to know information about its size. In developing countries, these animals are often used as working animals, mainly by poor populations in agricultural and livestock labor, but their use is decreasing in Brazil. Brazilian official data regarding donkeys and mules started to be measured at the agricultural census of 1960 and, from that time, eight agricultural censuses were published. But until the writing of this paper, no scientific paper was dedicated to the analysis of the results of the official agricultural censuses on the population of donkeys and mules in Brazil. Thus, we aim to compile and analyze the official Brazilian data from 1960 until 2017 to enhance the actions of stakeholders, researchers, and decision-makers concerned with Brazilian donkeys and mules.
\end{abstract}

Keywords: Donkey. Mules. Population size. Brazil.

\section{RESUMO}

Para entender e gerenciar melhor a população de jumentos e mulas é essencial saber informações sobre seu tamanho. Em países em desenvolvimento, esses animais são frequentemente usados como animais de trabalho, principalmente por populações pobres na agricultura e pecuária, mas seu uso está diminuindo no Brasil. Os dados oficiais brasileiros sobre jumentos e mulas começaram a ser mensurados no censo agrícola de 1960 e a partir dessa época foram realizados oito censos agrícolas. Até a redação deste artigo, porém, nenhum trabalho científico analisou os resultados dos censos agropecuários quanto à população de jumentos e mulas no Brasil. Deste modo, nosso objetivo é compilar e analisar os dados oficiais brasileiros de 1960 até 2017, para aprimorar as ações dos stakeholders, pesquisadores e tomadores de decisão preocupados com os jumentos e mulas brasileiras.

Palavras-chave: Jumentos. Muares. Tamanho populacional. Brasil.

\section{Correspondence to:}

Mariana Ramos Queiroz

Universidade de São Paulo, Faculdade de Medicina Veterinária

e Zootecnia, Departamento de Medicina Veterinária

Preventiva e Saúde Animal

Av. Prof. Orlando Marques de Paiva, 87

CEP: 05508-270, São Paulo - SP, Brasil

e-mail: mrqueiroz@usp.br

Received: August 31, 2020

Approved: December 22, 2020
How to cite: Queiroz MR, Gameiro MBP, Zanella AJ. The population of donkeys and mules in Brazil according to agricultural censuses from 1960 to 2017. Braz J Vet Res Anim Sci. 2021;58(special issue):e174365. https://doi. org/10.11606/issn.1678-4456.bjvras.2021.174365

\section{Introduction}

The last official estimate from the Food and Agriculture Organization of the United Nations for the donkey and mule population in Brazil was 822,255 and 1,252,029 
heads in 2018 (Food and Agricultural Organisation of the United Nations, 2020) ${ }^{1}$. In animal production, Brazil is mostly known for its global contribution to cattle, poultry, and pork production because of its importance to the country's economy. Nevertheless, the population of animals such as donkeys and mules starts to get attention mostly because of its 28\% decline between 2007 and 2017 (The Donkey Sanctuary, 2019).

Donkeys and mules often are managed as working animals in developing countries, due to their aptitude to work in difficult and challenging environments. In many of these places, they are used for the transport of goods with or without carts, can be ridden, and used to transport people, or in agriculture (Burn et al., 2010; Pritchard et al., 2005). Small donkeys can adapt to work in confined spaces and are easy to handle. Together with mules, they are the cheapest kind of agricultural worker because they are usually neglected regarding their needs for food, shelter (Pritchard et al., 2005), and even veterinary care.

Brazilian official data for donkeys and mules started to be measured at the agricultural census of 1960, with eight agricultural censuses carried out since then. The official data is related to animals that were on rural properties, or in common or open pastures, on the date of each census visit. Until the writing of this paper, to our knowledge, no scientific paper was dedicated to the analysis of the results of the official agricultural censuses on the population of donkeys and mules in Brazil. Thus, we aim to compile and analyze the official Brazilian data from 1960 until 2017 to enhance the actions of stakeholders, researchers, and decision-makers concerned with Brazilian donkeys and mules.

\section{Materials and Methods}

The main Brazilian agency that does population surveys and provides official data on Brazil is the Brazilian Institute of Geography and Statistics (IBGE). Data of donkeys and mules from the IBGE Automatic Recovery System (SIDRA) for the years 1995, 2006, and 2017 were collected, and for the previous years, the report of the Brazilian agricultural censuses of each year was aggregated and compiled (Instituto Brasileiro de Geografia e Estatística, 1960, 1970, 1975, 1980, 1985, 2020). Eight agricultural censuses were used, corresponding to the years 1960, 1970, 1975, 1980, 1985, 1995, 2006, and 2017. Information about the agricultural census includes data from rural areas and mainly the agrarian organization (ownership and land use), the profile of agricultural workers, and the

\footnotetext{
FAO's data about Brazilian animals populations are based on information provided by IBGE's agricultural censuses, annually updated according to statistical methods established by FAO.
}

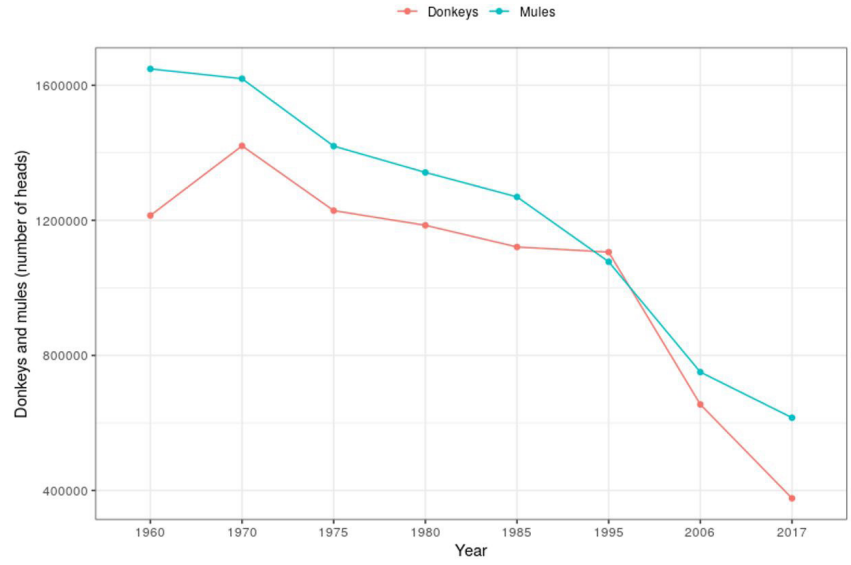

Figure 1-Time series between 1960 and 2017 with a population of donkeys and mules in Brazil.

technological level of the production processes. All analyses were performed by the R Core Team (2020) software.

\section{Results and Discussion}

Brazilian agricultural censuses periodically assess herds of donkeys and mules in rural properties since 1960. Table 1 presents the population of donkeys and mules from 1960 to 2017 , with a $65.9 \%$ and $42.9 \%$ decrease in the number of donkeys and mules, respectively, in Brazil. Figure 1 illustrates this decrease, especially in the last decades. The big difference probably occurred as a result of the rise of mechanization in the agricultural sector in the ' 90 s (Baer, 2003) and the importance represented by leather and its by-products as pointed out by Carneiro et al. (2018). The decrease in the Brazilian donkey population is associated with multiple factors. Among them, we can mention the rise of mechanization in the agricultural sector in the '90s (Baer, 2003) and the replacement of donkeys by motorized vehicles (Salles et al., 2013), mainly in the Northeast region of Brazil. Both circumstances caused a reduction in donkey utility and economic value, therefore leading to the abandonment or release of animals on roads. Roaming free, the animals were subjected to natural and non-natural deaths (as road accidents) ${ }^{2}$, and even became the raw material of unusual economic activities, such as leather and meat production ${ }^{3}$. While the project of creating a production chain of donkeys to supply the international market with by-products (Carneiro et al., 2018) was/is still not accomplished, the activity has developed in predatory conditions, contributing to the significant decrease of the donkey population in Brazil.

\footnotetext{
The impact of uncontrolled breeding cannot be captured by the IBGE's data since they do not refer to feral populations.

From 2013 to 2016, there was a 20\% increase in the worldwide industry of ejiao, a traditional Chinese medicine made from donkey skin (The Donkey Sanctuary, 2019).
} 
To better describe this decrease in population numbers, Table 2 presents the number of donkeys and mules by the main economic activities of the establishments between 1970 and 2017. Agriculture and livestock are the main economic activities employing donkeys and mules. The table shows a total decrease of $76.5 \%$ and $61.9 \%$ in the population of donkeys and mules, respectively, in Brazil.

Figure 2 highlights the main economic activities and demonstrates a shift between the 1985 and 1995 censuses over the kind of economic activity that most uses donkeys. With the mechanization of agricultural activities in the ' $90 \mathrm{~s}$
(Baer, 2003), the use of donkeys and mules to care for other livestock production became their main economic activity.

To further understand how the population of donkeys and mules is distributed within Brazil, we examined data from 1995 to 2017 by Brazilian regions verifying the location of the largest donkey and mule populations. Table 3 and Figure 3 show that the Northeastern region of Brazil has the largest number of donkeys and mules. In developing countries like Brazil, these animals are usually used to carry people, goods, and other items requiring transport (Burn et al., 2010; Pritchard et al., 2005).

Table 1 - The population of donkeys and mules (number of heads) between 1960 and 2017 in Brazil

\begin{tabular}{ccccccccc}
\hline Population & $\mathbf{1 9 6 0}$ & $\mathbf{1 9 7 0}$ & $\mathbf{1 9 7 5}$ & $\mathbf{1 9 8 0}$ & $\mathbf{1 9 8 5}$ & $\mathbf{1 9 9 5}$ & $\mathbf{2 0 0 6}$ & $\mathbf{2 0 1 7}$ \\
\hline Donkeys & 1214255 & 1420449 & 1228654 & 1185183 & 1121011 & 1105796 & 654714 & 376874 \\
Mules & 1648324 & 1619340 & 1419689 & 1341747 & 1269279 & 1077268 & 750529 & 615498 \\
\hline
\end{tabular}

Table 2 - The population of donkeys and mules (number of heads) between 1970 and 2017, by established economic activity (agriculture, livestock, mixed production, other economic activities) in Brazil. Note: Mixed production (agriculture and livestock) was not measured separately in 2006 and 2017

\begin{tabular}{lcccccccc}
\hline & Economic activity & $\mathbf{1 9 7 0}$ & $\mathbf{1 9 7 5}$ & $\mathbf{1 9 8 0}$ & $\mathbf{1 9 8 5}$ & $\mathbf{1 9 9 5}$ & $\mathbf{2 0 0 6}$ & $\mathbf{2 0 1 7}$ \\
\hline \multirow{2}{*}{ Donkeys } & Agriculture & 939715 & 893088 & 624060 & 572954 & 348466 & 239843 & 106673 \\
& Livestock & 333102 & 247072 & 462803 & 456791 & 427198 & 375791 & 250340 \\
& Mixed production & 118430 & 68152 & 53557 & 41402 & 275805 & - & - \\
& Others & 29202 & 20342 & 44763 & 49864 & 54327 & 39080 & 19861 \\
\multirow{4}{*}{ Mules } & Agriculture & 937483 & 853837 & 696560 & 635552 & 312529 & 196453 & 117528 \\
& Livestock & 479292 & 467126 & 551421 & 561171 & 564482 & 529326 & 482772 \\
& Mixed production & 170825 & 74838 & 60380 & 37194 & 177090 & - & - \\
& Others & 31740 & 23888 & 33386 & 35362 & 23167 & 24750 & 15198 \\
\hline
\end{tabular}

Notes: Agriculture corresponds to permanent and temporary crops; and Livestock corresponds to production of other animals.
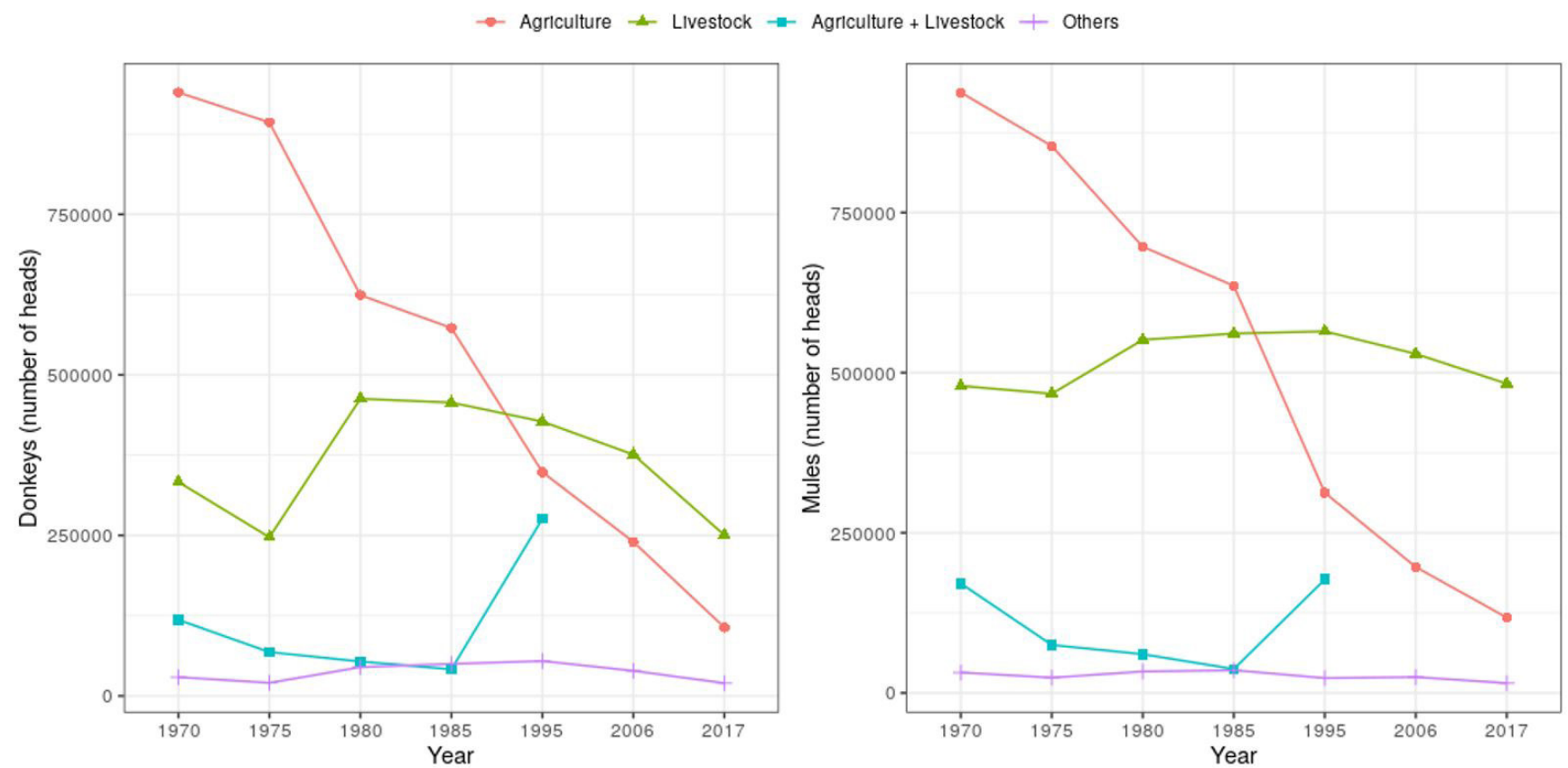

Figure 2 - Time series between 1970 and 2017 with a population of donkeys and mules, by established economic activity in Brazil. Notes: Agriculture corresponds to permanent and temporary crops, and Livestock corresponds to the production of other animals. 
Figure 4 notes that mules are more employed in other Brazilian regions (North, Midwest, Southeast, and South). Furthermore, in 2017, the number of mules in the Northeastern region is close to the sum of the population of mules in the North and Midwest regions (Table 3). Investigating further, since the Northeastern region always had more donkeys and mules than the other regions (Figure 3), we found that Bahia is the state with more donkeys and mules in the country, as shown in Table 4 and Figures 5 and 6.

This paper examines the evolution of Brazilian official data regarding donkeys and mules from rural areas, although it did not contemplate feral donkeys and mules. Municipal
Livestock Production data were not used because the IBGE stopped collecting data on animals used for traction and transportation (Instituto Brasileiro de Geografia e Estatística, 2013a). This is especially true in the Northeast region since these animals were replaced by motorcycles and other vehicles in the rural area, implying a scenario of animals without owners, i.e. feral donkeys and mules wandering around (Instituto Brasileiro de Geografia e Estatística, 2013b). We hope this study can help decision-makers and stakeholders create actions to stop the decreasing numbers of these animals and to encourage further research with feral donkeys and mules.
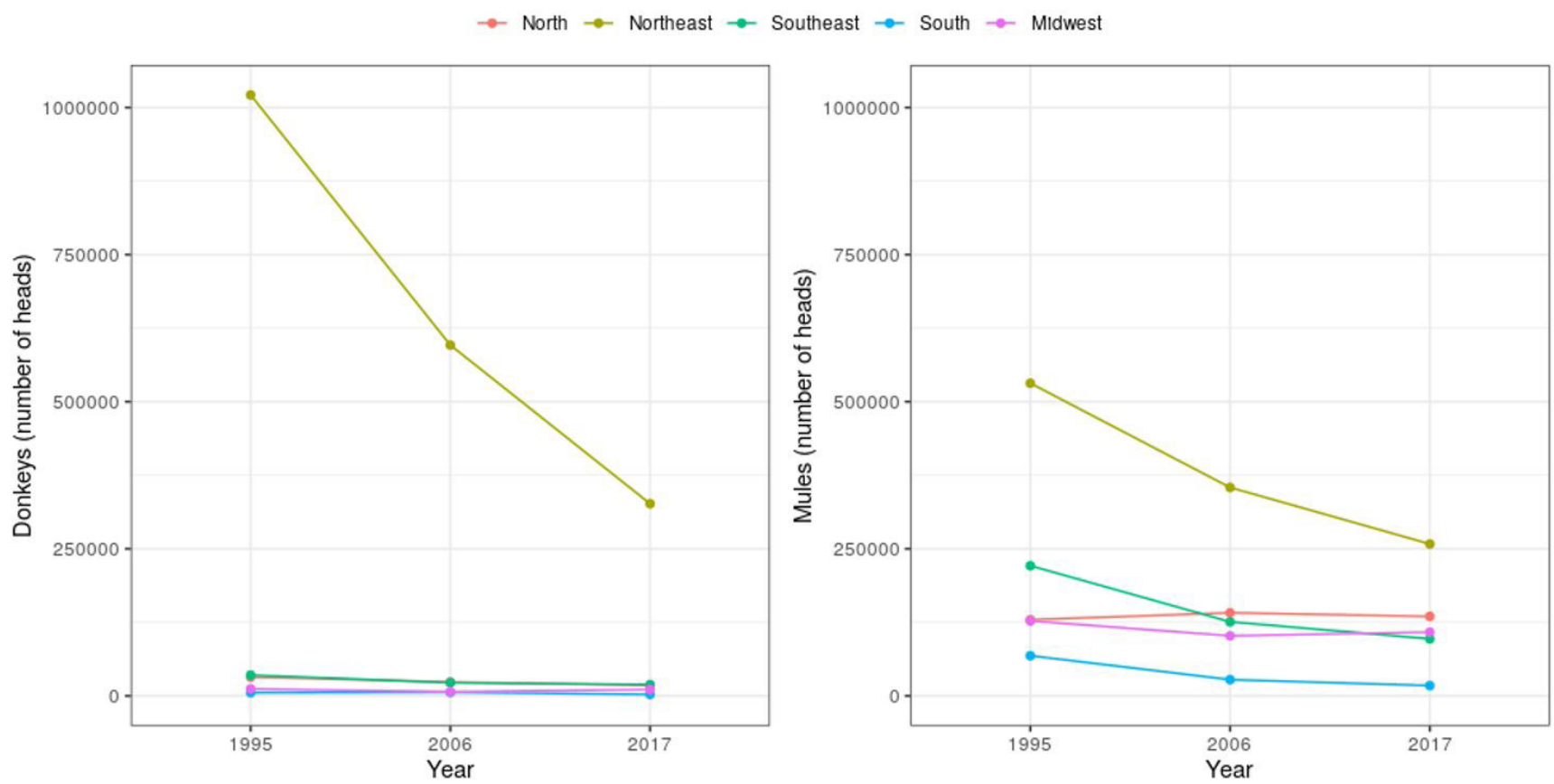

Figure 3 - The total population of donkeys and mules between 1995 and 2017, by Brazilian region.

Table 3 - The population of donkeys and mules (number of heads) between 1995 and 2017, by Brazilian region

\begin{tabular}{|c|c|c|c|c|c|c|}
\hline \multirow{2}{*}{ Brazilian region } & \multicolumn{3}{|c|}{ Donkeys } & \multicolumn{3}{|c|}{ Mules } \\
\hline & 1995 & 2006 & 2017 & 1995 & 2006 & 2017 \\
\hline North & 31911 & 23460 & 18068 & 129407 & 141094 & 135029 \\
\hline Northeast & 1021384 & 596189 & 326569 & 531375 & 354184 & 258090 \\
\hline Southeast & 35266 & 22309 & 19069 & 221114 & 125731 & 96845 \\
\hline South & 5420 & 6076 & 2457 & 68119 & 27502 & 17382 \\
\hline Middle West & 11815 & 6680 & 10711 & 127253 & 102018 & 108152 \\
\hline
\end{tabular}

Table 4 - The population of donkeys and mules (number of heads) between 1995 and 2017, by the states of the Northeastern Brazilian region

\begin{tabular}{|c|c|c|c|c|c|c|}
\hline \multirow{2}{*}{ Brazilian states } & \multicolumn{3}{|c|}{ Donkeys } & \multicolumn{3}{|c|}{ Mules } \\
\hline & 1995 & 2006 & 2017 & 1995 & 2006 & 2017 \\
\hline Maranhão & 144026 & 71097 & 41147 & 118315 & 67372 & 56827 \\
\hline Piauí & 194429 & 113251 & 50718 & 38099 & 28655 & 18679 \\
\hline Ceará & 193176 & 106701 & 53233 & 77266 & 50678 & 37918 \\
\hline Rio Grande do Norte & 49677 & 25834 & 14860 & 12017 & 9232 & 9633 \\
\hline Paraíba & 64071 & 46573 & 30555 & 22056 & 15636 & 13755 \\
\hline Pernambuco & 57158 & 47384 & 26546 & 38535 & 27850 & 18364 \\
\hline Alagoas & 5791 & 7544 & 7873 & 13116 & 8732 & 7018 \\
\hline Sergipe & 9666 & 8930 & 8483 & 13389 & 10942 & 8953 \\
\hline Bahia & 303390 & 168875 & 93154 & 198582 & 135087 & 86943 \\
\hline
\end{tabular}




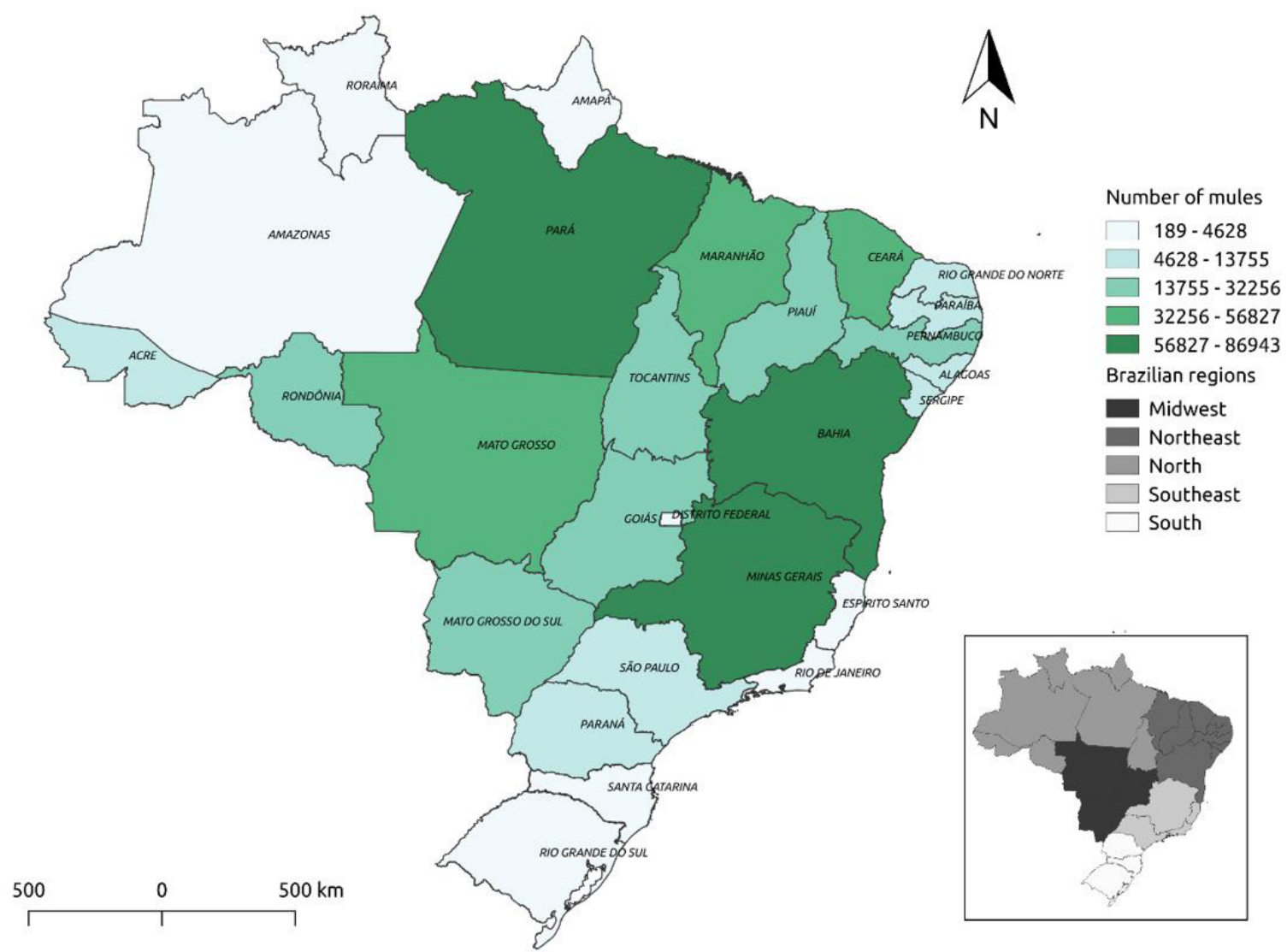

Figure 4 - Thematic map of the population of mules in each state and the Federal District in Brazil, according to the 2017 Brazilian agricultural census.

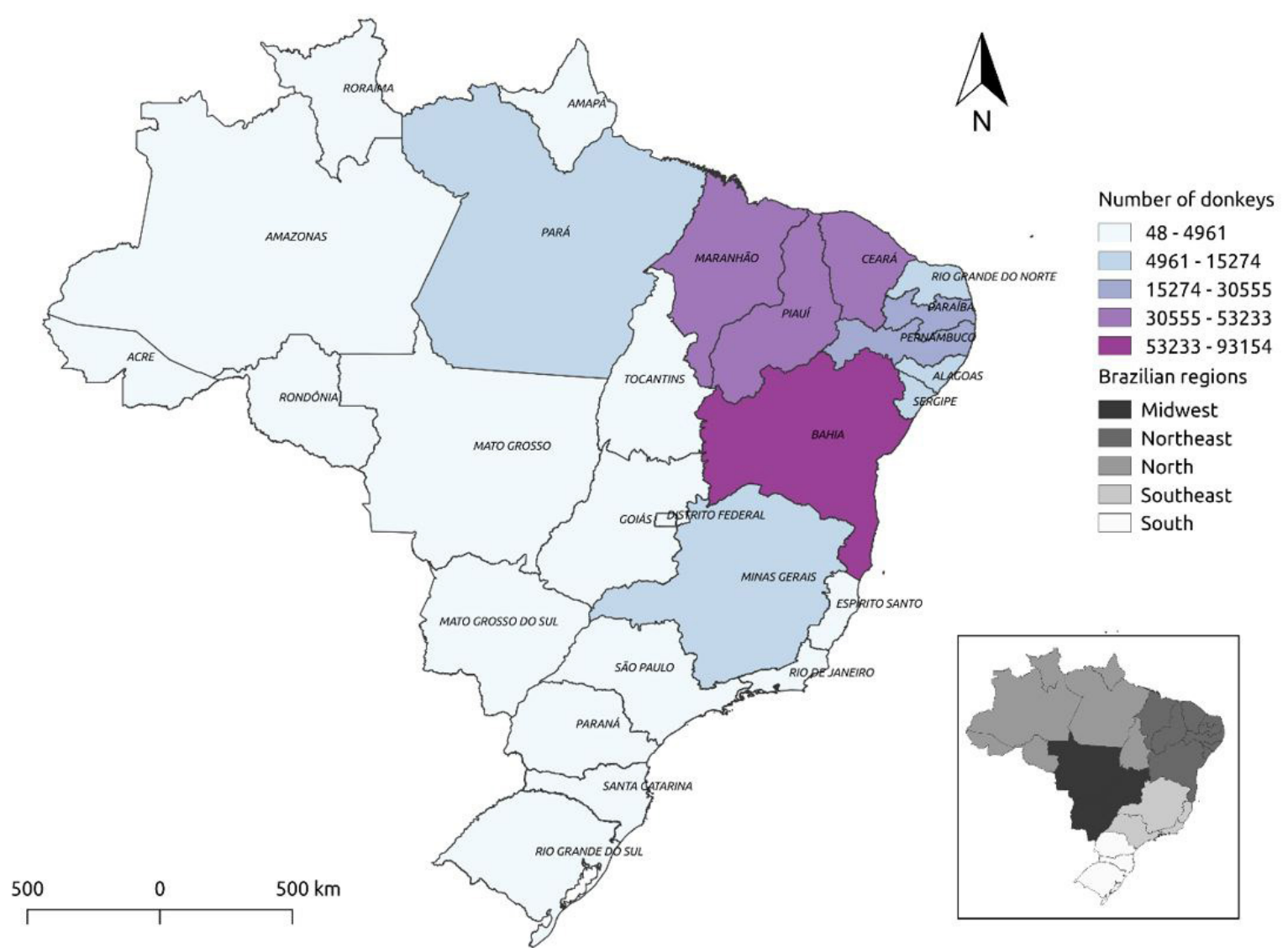

Figure 5 - Thematic map of the population of donkeys at each state and the Federal District in Brazil, according to the 2017 Brazilian agricultural census. 


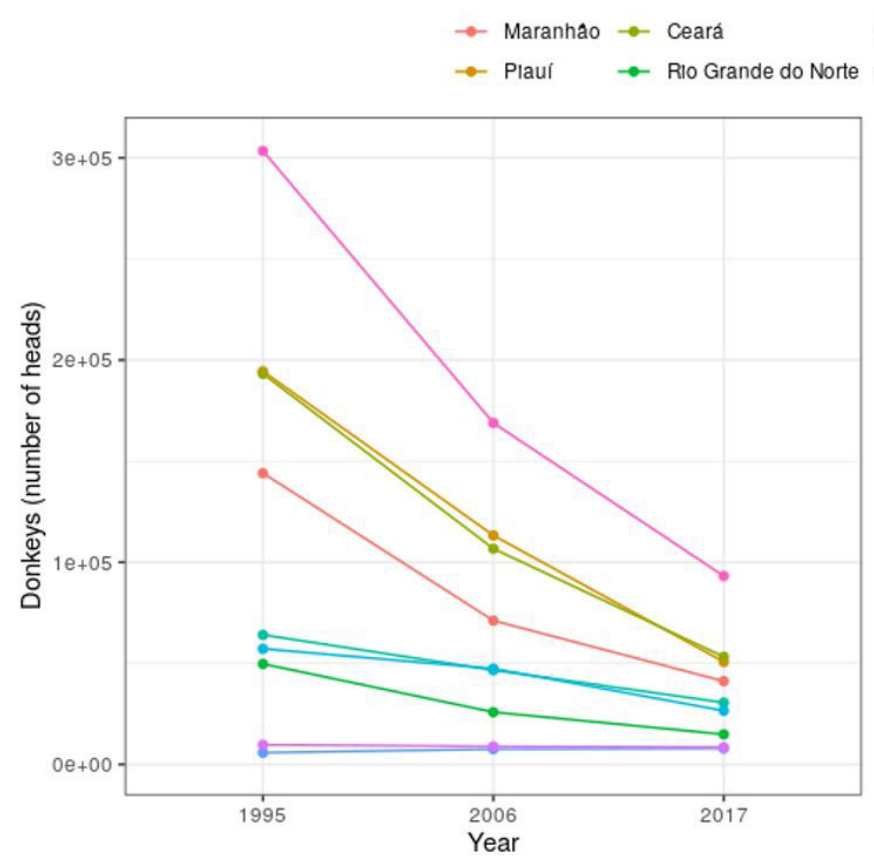

$\rightarrow$ Paraiba $\rightarrow$ Alagoas $\rightarrow$ Bahla

- Pernambuco $\rightarrow$ Sergipe

Figure 6 - The total population of donkeys and mules between 1995 and 2017, in the states of the Northeastern Brazilian region.

\section{Conclusion}

Although this data does not concern feral donkeys and mules, the historical official numbers of the population size help to describe their population decrease changes throughout Brazil and contribute to the enhancement of actions from stakeholders, researchers, and decision-makers concerned with donkeys and mules.

\section{Conflict of Interest}

The authors declare that they have no competing interests.

\section{References}

Baer W. A economia brasileira. 2. ed. São Paulo: Nobel; 2003.

Burn CC, Dennison TL, Whay HR. Environmental and demographic risk factors for poor welfare in working horses, donkeys and mules in developing countries. Vet J. 2010;186(3):385-92. http://dx.doi.org/10.1016/j. tvjl.2009.09.016. PMid:19926316.

Carneiro GF, Lucena JEC, Barros LO. The current situation and trend of the donkey industry in South America. J Equine Vet Sci. 2018;65:106-10. http://dx.doi.org/10.1016/j. jevs.2018.03.007.

Food and Agricultural Organisation of the United Nations - FAO. FAO statistical database website [Internet]. Rome: FAO; 2020 [cited 25 Aug 2020]. Available from: http:// www.fao.org/faostat/en/\#data/QA

\section{Ethics Statement}

This article does not contain any studies with animals performed by any of the authors.

\section{Acknowledgements}

The authors acknowledge financial support from the Coordination for the Improvement of Higher Education Personnel - Brazil (CAPES) - Finance Code 001, and The Donkey Sanctuary.

Instituto Brasileiro de Geografia e Estatística - IBGE. Censo agrícola [Internet]. Rio de Janeiro: IBGE; 1960 [cited 15 Nov 2020] Available from: https://biblioteca.ibge.gov.br/ visualizacao/periodicos/44/ca_1960_v2_p2_br.pdf

Instituto Brasileiro de Geografia e Estatística - IBGE. Censo agropecuário Brasil [Internet]. Rio de Janeiro: IBGE; 1970 [cited 15 Nov 2020] Available from: https://biblioteca.ibge. gov.br/visualizacao/periodicos/45/ca_1970_v3_br.pdf

Instituto Brasileiro de Geografia e Estatística - IBGE. Censo agropecuário Brasil [Internet].Rio de Janeiro: IBGE; 1975 [cited 15 Nov 2020] Available from: https://biblioteca.ibge. gov.br/visualizacao/periodicos/243/agro_1975_v1_br.pdf

Instituto Brasileiro de Geografia e Estatística - IBGE. Censo agropecuário Brasil [Internet]. Rio de Janeiro: 
IBGE; 1980 [cited 15 Nov 2020] Available from: https:// biblioteca.ibge.gov.br/visualizacao/periodicos/46/ ca_1980_v2_t3_n1_br.pdf

Instituto Brasileiro de Geografia e Estatística - IBGE. Censo agropecuário Brasil [Internet]. Rio de Janeiro: IBGE; 1985 [cited 15 Nov 2020] Available from: https://biblioteca.ibge. gov.br/visualizacao/periodicos/47/ca_1985_n1_br.pdf

Instituto Brasileiro de Geografia e Estatística - IBGE. Produção da pecuária municipal [Internet]. Rio de Janeiro: IBGE; 2013a. (v. 41) [cited 15 Nov 2020] Available from: https://biblioteca.ibge.gov.br/visualizacao/periodicos/84/ ppm_2013_v41_br.pdf

Instituto Brasileiro de Geografia e Estatística - IBGE. Proposta de reformulação da pesquisa da pecuária municipal [Internet]. Rio de Janeiro: IBGE; 2013b [cited 15 Nov 2020] Available from: https://www.ibge.gov.br/arquivo/projetos/ prpa/Reformulacao_da_PPM_2013.pdf

Instituto Brasileiro de Geografia e Estatística - IBGE. Sistema IBGE de Recuperação Automática - SIDRA [Internet]. Rio de Janeiro: IBGE; 2020 [cited 15 Nov 2020]. Available from: https://sidra.ibge.gov.br/pesquisa/censo-agropecuario/ censo-agropecuario-2017
Pritchard JC, Lindberg AC, Main DCJ, Whay HR. Assessment of the welfare of working horses, mules and donkeys, using health and behaviour parameters. Prev Vet Med. 2005;69(3-4):265-83. http://dx.doi.org/10.1016/j. prevetmed.2005.02.002. PMid:15907574.

Salles PA, Sousa LO, Gomes LPB, Barbosa VV, Medeiros GR, Sousa CM, Weller M. Analysis of the population of equidae in semiarid region of Paraíba. J Biotechnol Biodivers. 2013;4(3):26975. http://dx.doi.org/10.20873/jbb.uft.cemaf.v4n3.salles.

R Core Team. R: a language and environment for statistical computing [Internet]. Vienna: R Foundation for Statistical Computing; 2020 [cited 15 Nov 2020]. Available from: https://www.R-project.org/.

The Donkey Sanctuary. Under the skin: update on the global crisis for donkeys and the people who depend on them. Devon; 2019 [cited 13 Nov 2020] Available from: https:// www.thedonkeysanctuary.org.uk/sites/uk/files/2019-12/ under-the-skin-report-english-revised-2019.pdf

Financial Support: Coordination for the Improvement of Higher Education Personnel - Brazil (CAPES) - Finance Code 001, and The Donkey Sanctuary. 